\title{
A Leg Purpura Revealing an Infectious Endocarditis
}

\author{
Oukarfi Sara*, Douhi Zakia, Rasso Asmae, Elloudi Sara, Baybay Hanane and Mernissi FZ \\ Department of Dermatology and Venerology, Hospital University Hassan II, Morocco
}

*Corresponding author: Oukarfi Sara, Department of Dermatology and Venerology, Hospital University Hassan II, route sidi Hrazem, BP:1835, 30050, Fez, Morocco.

To Cite This Article: Oukarfi Sara, A Leg Purpura Revealing an Infectious Endocarditis. 2020 - 8(1). AJBSR.MS.ID.001230.

DOI: 10.34297 /AJBSR.2020.08.001230.

Received: 阱 March 02, 2020; Published: 制 March 10, 2020

Introduction

Infectious endocarditis (IE) is a rare infection of one or more cardiac valves, by a microorganism, most often bacterial, more rarely by intracellular germs or yeasts, it is a sepsis grafted on a preexisting heart disease or in a healthy subject. It is suspected in a patient with heart symptoms with fever [1]. IE is a rare disease with a poor prognosis. Dermatological lesions are infrequent and neglected by non-dermatologist practitioners. We report a case of IE revealed by a purpura in the legs.

Keywords: Infectious Endocarditis; Purpura; Cutaneous Manifestations of Infectious Endocarditis

\section{Observation}

A 42-year-old patient, followed for an undocumented valvulopathy since his childhood on treatment, admitted to emergency in an oedemato-ascitic syndrome with acute dyspnea, urinary burns, associated with dermatological lesions evolving

for two days without a fever. Our opinion was sought for purpuric lesions of the legs. On general examination, the patient was dyspneic, pale, with soft white bilateral lower limb edema down to the knees.

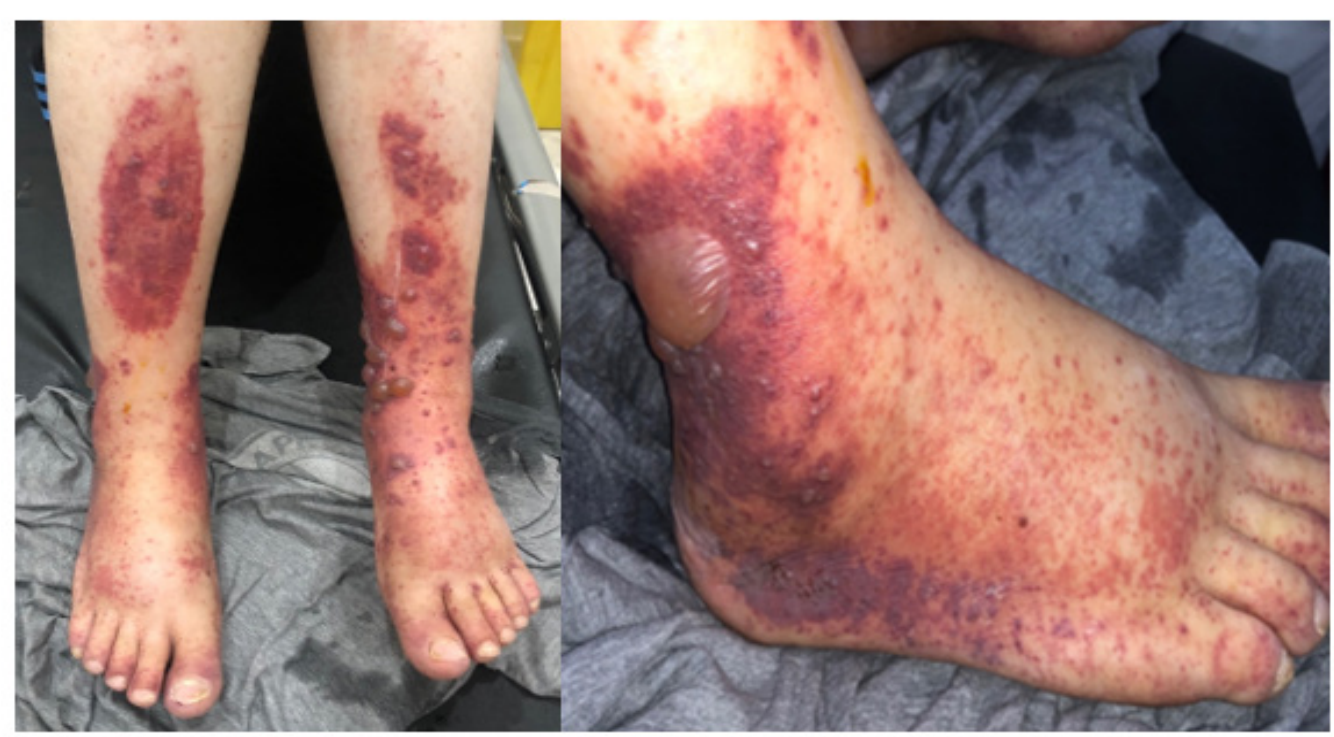

Figure 1\&2: Infiltrated purpura in the legs surmounted by bullous lesions. 


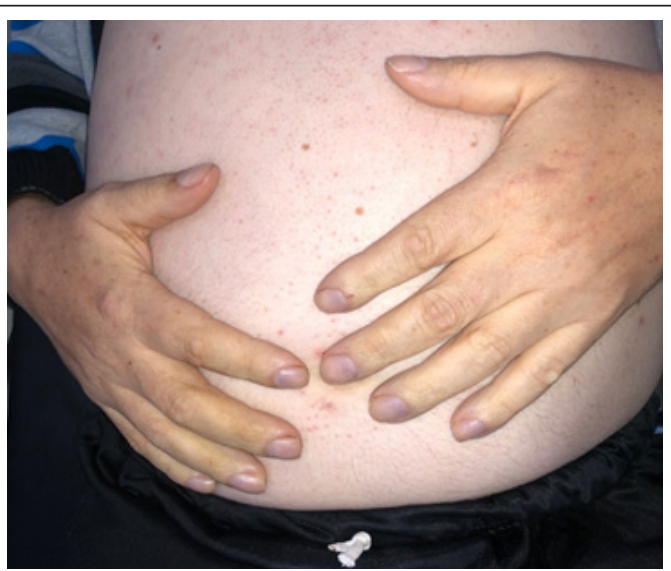

Figure 3: Pallor with digital hypocratism.

The dermatological examination objectified an infiltrated purpuric cupboards of irregular infiltrated contours with the presence of petechiae of variable size surmounted by blisters with clear content confluent in places sitting at the level of the 2 anterior faces of the legs, the 2 feet and at the level of abdomen. Digital hippocratism, an ascites of great abundance. Signs of global heart failure the rest of the examination was normal (Figures 1-3).

The trans-thoracic cardiac ultrasound showed a $10 \mathrm{~mm}$ hyperechoic aortic vegetation, severe aortic insufficiency with left ventricular dilation in favor of infective endocarditis. A purpura skin biopsy revealed leukocytoclastic vasculitis. The patient was hospitalized in cardiology, put on ceftriaxone and gentamycin with close monitoring.

\section{Discussion}

Clinical diagnosis of IE is often based on fever and cardiac signs, dermatological signs are rare, the main dermatological manifestations described during acute or subacute IE include Osler nodules, Janeway erythema, petechial purpura and subnail splinter haemorrhage [1]. Petechial purpura is frequent, occurring at the mucous level (palate, conjunctiva) and / or skin (trunk, extremities, neck), sometimes necrotic, extensive as in this observation. Janeway's erythema is macular, haemorrhagic, reddish brown in color with irregular outline, angular, not tense and painless, of palmoplantar localization. Janeway's purpura and erythema preferentially associate with acute AEs [2].

For Osler nodules, they most often associate with subacute bacterial AEs, they are erythematous nodules with a sometimeswhitish center, of variable size, tense, indurated, round or oval and painful. They sit with predilection on the palms and soles. Splinter hemorrhages under nail in particular on the third finger and of proximal localization, constitute a classic sign of call during the infectious endocarditis but are not very specific $[2,3]$. Other dermatological manifestations have been occasionally reported: distal necrosis of the extremities by acute ischemia of embolic origin and cross-linked livedo of the lower limbs. Ecthyma gangrenosum is a septic cutaneous manifestation conventionally associated with Pseudomonas AE. Digital hippocratism and Sweet syndrome have also been described in subacute bacterial AEs.

The pathophysiology of these different cutaneous manifestations is schematically based on two mechanisms: septic embolism and deposits of circulating immune complexes due to the histological presence of leukocytoclastic vasculitis during purpura and within Osler nodules. These dermatological manifestations can be a predictor of neurological complications. The majority of dermatological lesion result from a thrombotic process of embolic origin, their appearance would reflect an evolving embolic process from the vegetations which can reach the other organs. The good knowledge of those signs allows patricians to lead to the diagnosis of IE and the systematic search for these dermatological manifestations therefore has a prognostic and therapeutic interest [4].

\section{Conclusion}

Purpuric lesions in a cardiac person lead to think of an infectious endocarditis even in the absence of fever and should alert the clinician to look for other secondary embolic complications.

\section{Declaration of Interests}

None.

\section{References}

1. Cahill TJ, Prendergast BD (2016) Infective endocarditis. The Lancet 387(10021): 882-893.

2. Gunson TH, Oliver GF (2007) Osler's nodes and Janeway lesions. Australas J Dermatol 48(4): 251-255.

3. (2008) Infective endocarditis, Images en Dermatologie, juillet-août 1(3).

4. Servy A, Valeyrie Allanore L, Alla F, Duval X, Chosidow O (2011) Intérêt pronostique des manifestations cutanées dans l'endocardite infectieuse. Annales de Dermatologie et de Vénéréologie 138(12): A59. 